\title{
Javier Figuero, Albert Camus ou l'Espagne exaltée
}

\section{Gian Luigi Di Bernardini}

\section{(2) OpenEdition}

\section{Journals}

\section{Edizione digitale}

URL: http://journals.openedition.org/studifrancesi/7016

DOI: 10.4000/studifrancesi.7016

ISSN: 2421-5856

\section{Editore}

Rosenberg \& Sellier

\section{Edizione cartacea}

Data di pubblicazione: 1 septembre 2010

Paginazione: 403

ISSN: 0039-2944

\section{Notizia bibliografica digitale}

Gian Luigi Di Bernardini, «Javier Figuero, Albert Camus ou l'Espagne exaltée», Studi Francesi [Online], 161 (LIV | II) | 2010, online dal 30 novembre 2015, consultato il 09 janvier 2021. URL: http:// journals.openedition.org/studifrancesi/7016 ; DOI: https://doi.org/10.4000/studifrancesi.7016

Questo documento è stato generato automaticamente il 9 janvier 2021.

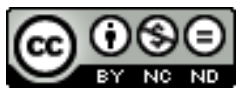

Studi Francesi è distribuita con Licenza Creative Commons Attribuzione - Non commerciale - Non opere derivate 4.0 Internazionale. 


\title{
Javier Figuero, Albert Camus ou l'Espagne exaltée
}

\author{
Gian Luigi Di Bernardini
}

\section{NOTIZIA}

JAVIER FIGUERo, Albert Camus ou l'Espagne exaltée, Paris, Autre temps, 2008, pp. 277.

1 L'autore, un giornalista e scrittore madrileno, dedica questo suo lavoro alla presenza, estensiva e multiforme, della Spagna nella vita e nell'opera di Albert Camus. L'origine di questo fenomeno va in primo luogo ascritta a ragioni biografiche: la madre dello scrittore algerino, infatti, era spagnola. Camus rimase sempre legatissimo alla madre, con cui condivise le considerevoli difficoltà economiche che così profondamente segnarono la sua infanzia dapprima e influenzarono il suo pensiero di adulto poi.

2 In un percorso articolato in cinque capitoli, l'autore ricostruisce le tappe principali della biografia dell'autore, passando appunto dall'infanzia in Algeria al dramma della guerra civile spagnola, al bisogno di riscatto e al grande amore per l'attrice spagnola Maria Casarès, fino a giungere al premio Nobel e alla morte.

3 La ricostituzione della biografia dell'autore si alterna a momenti di analisi tematica (centrata, in particolar modo, sulle diverse declinazioni della presenza della Spagna) e strutturale delle opere di cui si parla, senza dimenticare di concedere il giusto spazio alla ricostruzione degli eventi storici che formano il quadro in cui l'azione umana, politica e letteraria di Camus si colloca. 